\title{
FOOD FOR THE TWENTY-FIRST CENTURY: AN ANALYSIS OF REGULATIONS FOR GENETICALLY ENGINEERED FOOD IN THE UNITED STATES, CANADA, AND THE EUROPEAN UNION
}

\author{
Sara J. MacLaughlin*
}

\section{INTRODUCTION}

Imagine being able to eat a pork chop while getting the health benefit of spinach. ${ }^{1}$ Soon, this might be possible as Japanese researchers claim to have implanted a plant gene, specifically that of spinach, into pigs, creating a pig that is healthier to eat. ${ }^{2}$ Is this a hoax? Is it possible, that the human race has advanced into the realm of science fiction? Could there really be an attack of killer tomatoes? ${ }^{3}$ In reality, scientists are actually able to implant genes from one species of a plant or animal into another species in order to "create" a new plant or animal with desired traits. ${ }^{4}$ Such biotechnological advances are already used in the fields of pharmaceutical research, manufacturing, and crop plant modification. ${ }^{5}$ Scientists currently can manufacture protein-based drugs from the milk-producing animals, including cows and goats. ${ }^{6}$ Also, scientists

* J.D. Candidate, 2004, Indiana University School of Law - Indianapolis. B.A. Biology, Manchester College, 1997. The author wishes to thank her husband and family for their support, encouragement, and patience throughout law school.

1. See Emma Young, GM Pigs are Both Meat and Veg, NEw SCIENTIST, Jan. 25, 2002, available at http://www.newscientist.com/hottopics/gm (last visited Oct. 31, 2003).

2. See id.

3. Bad reference to the 1980 movie ATTACK OF KILLER TOMATOES (Media/Fox Video 1980). However, it should be pointed out that the first genetically modified food approved for sale in the marketplace was the Flavr Savr brand of tomatoes, introduced by Calgene, Inc. See Food and Agric. Org. of the United Nations, FAO Ethics Series 2, Genetically Modified Organisms, Consumers, Food Safety and the Environment (2001), at http://www.fao.org/ DOCREP/003/X9602E/x9602e05.htm (last visited Oct. 31, 2003) [hereinafter FAO Ethics]. Flavr Savr tomatoes were "modified to delay ripening and they therefore had a prolonged shelflife." Id. However, consumers noted that Flavr Savr tomatoes were more expensive than traditional tomatoes, had soft skin and a strange taste. See id.

4. See generally FAO Ethics, supra note 3.

5. See Carol Lewis, A New Kind of Fish Story: The Coming of Biotech Animals, FDA CONSUMER MAG., Jan._Feb. 2001, available at http://www.cfsan.fda.gov/ dms/fdbiofsh.html (last visited Oct. 31, 2003).

6. See id. Pharmaceutical products produced by genetic engineering that are either available or are in clinical testing include products to treat diabetes (insulin), cancer (interleukin-2, gamma interferon), hepatitis (Hepatitis B vaccine), burns, anemia, dwarfism, and hemophilia. See William S. Klug \& Michael R. Cummings, ConcePts OF Genetics 432 (4th ed. 1994). 
using one specific form of modern biotechnology, ${ }^{7}$ are able to "create" crop plants modified to contain desired traits. ${ }^{8}$ This type of biotechnology has already been introduced into the human food chain in many countries around the world. ${ }^{9}$

Genetic engineering ${ }^{10}$ is being used to create food products that are beneficial to producers and to consumers. ${ }^{11}$ Technology enables scientists to create tomatoes that delay ripening, thus enhancing their shelf life. ${ }^{12}$ Scientists also have created herbicide tolerant corn and pest resistant cotton. ${ }^{13}$ Genetic engineering can also modify food to include specific nutrients, such as rice that has been modified to contain vitamin A. ${ }^{14}$ This type of modification can be particularly beneficial in third world nations where there is a shortage of food and many people are nutrient deprived..$^{15}$ However, this same technology has been criticized for primarily benefiting the rich, while the poor and hungry suffer without the benefit of biotechnology. ${ }^{16}$

7. See Cartagena Protocol on Biosafety to the Convention on Biological Diversity, Jan. 29, 2000, art. 3(i), 39 I.L.M. 1027. The Cartagena Protocol on Biosafety defines "modern biotechnology" as applying the following techniques:

a. In vitro nucleic acid techniques, including recombinant deoxyribonucleic acid (DNA) and direct injection of nucleic acid into cells or organelles, or

b. Fusion of cells beyond the taxonomic family, that overcome natural physiological reproductive or recombination barriers and that are not techniques Id. used in traditional breeding and selection.

8. See KLUG \& CUMmingS, supra note 6 , at 432 . Herbicide-resistant plants are a modification that scientists create using genetic engineering. See id.

9. See Douglas Herbert, Science Bakes a GM Baguette, CNN, Jan. 16, 2001, available at http://www.cnn.com/2001/WORLD/europe/01/15/genetic.bread/index.html (last visited Oct. 31, 2003). Countries with GM food products include Australia, South Africa, Mexico, Spain, France, Portugal, Romania, and the Ukraine. See id. As of Jan. 16, 2001, Brazil did not allow, "the sowing of GM crops." Id. The United States, Canada, Argentina, and China are the world's top four countries for plant biotechnology research. See FRED GALE ET AL., U.S. DEP'T OF AGRIC., IS BIOTECHNOLOGY IN CHINA's FUTURE? 34 (2002).

10. See KLUG \& CUMMINGS, supra note 6, app. B-8. Genetic engineering is defined as "The technique of altering the genetic constitution of cells or individuals by the selective removal, insertion, or modification of individual genes or gene sets." Id. Food produced through such technology can be called a variety of names, including genetically engineered, genetically modified, genetically modified organism (GMO), modern biotechnology, and foods derived through recombinant DNA techniques. See CTR. FOR FOOD SAFETY AND APPLIED NUTRITION, U.S. FOOD AND DRUG ADMIN., REPORT ON CONSUMER FOCUS GROUPS ON BIOTECHNOLOGY, at http://vm.csfan.fda.gov/ comm/biorpt.html (last visited Oct. 31, 2003).

11. See generally FAO Ethics, supra note 3.

12. See id.

13. See U.S. Food and Drug Administration Center for Food Safety \& Applied Nutrition, List of Completed Consultations on Bioengineered Foods (2002), at http://www.cfsan.fda.gov/ -lrd/biocon.html (last visited Oct. 31, 2003) [hereinafter Completed Consultations].

14. See FAO Ethics, supra note 3.

15. See id.

16. See id. 
This Note examines and compares the regulations of Canada, the United States, and the European Union concerning environmental protection and food safety issues of genetically modified foods, including specific issues pertaining to transgenic animals. ${ }^{17}$ Additionally, this Note analyzes consumer acceptance of genetically engineered foods in Canada, the United States, and the European Union. Part II of the Note provides some information on genetic engineering of both plants and animals. Part III of the Note explores Canada's regulatory processes concerning products produced through genetic engineering. Specifically, this section examines how Canada regulates these processes for food safety, the environment, and transgenic animals. Part IV addresses the United States approach to products produced from genetic engineering, again focusing on food safety, environmental concerns, and transgenic animals. Part $\mathrm{V}$ of the Note examines the European Union's regulatory scheme for genetically engineered products, again focusing on their relation to food safety, environmental concerns, and transgenic animals. Part VI of the Note compares the three governments' approaches to products produced via genetic engineering and attempt to find similarities between the approaches.

\section{GENETIC ENGINEERING}

\section{A. General Overview}

In the not so distant future, perhaps even tonight, when you go to the grocery store, you will find novel food ${ }^{18}$ products produced through a

17. See Office of Biotechnology, Canadian Food Inspection Agency, How Many Genetically Modified Food Products are Permitted in Canada, at http://www.inspection.gc.ca/english/sci/biotech/safsal/novalie.shtml (last visited Oct. 31, 2003) [hereinafter Canada's GMOs]. See also Transgenic Fish, infra note 205; EU Questions, infra note 228. A transgenic organism is defined as, "An organism formed by the insertion of foreign genetic material into the germ line cells of organisms. Recombinant DNA techniques are commonly used to produce transgenic organisms." Industry Canada, Life Sciences Branch, Glossary (2002), at http://strategis.ic.gc.ca/SSG/bv00373e.html (last visited Oct. 31, 2003) [hereinafter Glossary].

18. See Glossary, supra note 17. This paper focuses on novel food products that contain a genetically modified organism (GMO) which are also called "living modified organism (LMO) or transgenic organism." Id.

Canada defines novel food as:

a) [A] substance, including a microorganism, that does not have a history of safe use as a food;

b) a food that has been manufactured, prepared, preserved or packaged by a process that

1. has not been previously applied to that food, and

2. causes the food to undergo a major change; and

c) a food that is derived from a plant, animal or microorganism that has been genetically modified such that

1. the plant, animal or microorganism exhibits characteristics that were not previously observed in that plant, animal or microorganism,

2. the plant, animal or microorganisms no longer exhibits characteristics that 
scientific process to contain enviable traits or created to exclude some undesirable qualities. ${ }^{19}$ Thus, sharing the shelf space with traditional items such as corn, lettuce, and broccoli will be such items as "[i]nsect-resistant apples, long-lasting raspberries, and potatoes that absorb less fat." ${ }^{20}$ These novel products are the results of advances in biotechnology, specifically genetic engineering. ${ }^{21}$

Genetic engineering is a process that allows scientists "to modify the genetic makeup" of an organism "precisely and predictably, creating improved varieties faster and easier than can be done using more traditional . . . techniques." ${ }^{22}$ Genetic engineering uses a process called "recombinant DNA [rDNA] technology."23 This process allows researchers to "isolate a known trait from any living species-plant, animal or microbe-and incorporate it into another species." ${ }^{24}$

\section{B. History of Modifying Plants to Display Desired Characteristics}

Although genetic engineering sounds like a new or futuristic idea, it has existed for years. ${ }^{25}$ In the 1800 s, Gregor Mendel ${ }^{26}$ began to experiment with hybridization ${ }^{27}$ in garden pea plants. ${ }^{28}$ Mendel is credited with discovering

3. were previously observed in that plant, animal or microorganism, or
one or more characteristics of the plant, animal or microorganism no
longer fall within the anticipated range for that plant, animal, or
microorganism. microorganism.
ations, C.R.C., ch. 870, § B.28.001 (1999) (Can.).

Novel Foods Regulations, C.R.C., ch. $870, \S$ B.28.001 (1999) (Can.).
19. See John Henkel, Genetic Engineering Fast Forwarding to the Future, FDA CONSUMER MAG, Feb. 1998, at http://www.fda.gov/bbs/topics/CONSUMER/geneng.html (last visited Oct. 31, 2003).

20. Id. Other types of GM food products include cotton, rice, wheat, corn, soybean, rapeseed, tobacco, peanut, cabbage, tomato, sweet pepper, and petunia. See GALE, supra note 9 , at 34 .

21. See Henkel, supra note 19.

22. Id.

23. Id.

24. Id. Traits are contained in genes, which are segments of deoxyribonucleic acid (DNA). See id. DNA is "found in all living cells." ld.

25. See id.

26. See KLug \& CummingS, supra note 6, at 51. Gregor Mendel was born in 1822 in what is now the Czech Republic. See id. He studied philosophy before attending the University of Vienna to study physics and botany. See id. Mendel researched genetics until he left research to fulfill his elected post as abbot of a monastery. See id. Mendel's research succeeded where other researchers had failed in part because he "restricted his examination to one or very few pairs of contrasting traits in each experiment." Id. at 52.

27. See Larry Thompson, Are Bioengineered Foods Safe?, FDA ConsuMER MAG., Jan.-Feb. 2000, available at http://www.fda.gov/fdac/features/2000/100_bio.html (last visited Oct. 31,2003 ). Hybridization is a process "in which two related plants were cross-fertilized and the resulting offspring had characteristics of both parent plants. Breeders then selected and reproduced the offspring that had desired traits." Id.

28. See KLUG \&CUMMINGS, supra note 6, at 51. 
"the basis for the transmission of hereditary traits." 29 Indeed, the process of gene selection has existed since ancient times. ${ }^{30}$ Ancient farmers practiced a crude form of gene selection by saving seeds from the plants that were the "hardiest and most resistant to disease." 31 These ancient farmers " "engineered" new combinations of genes, ones that would produce superior plant stock." ${ }^{\text {"32 }}$ They engineered these superior plants " $[\mathrm{b}] \mathrm{y}$ selecting which plants they would breed." ${ }^{3}$ As should be expected, modern day genetic engineering offers scientists a more predictable and faster way of trait selection. ${ }^{34}$

\section{Potential Benefits \& Detriments of Genetically Modified (GM) Products}

\section{GM Benefits}

"To feed 10.8 billion people by 2050 will require us to convert 15 million square miles of virgin forest, wilderness and marginal land into agrochemical-dependent arable land. GM crops hold the most important key to solve future problems in feeding 5 billion mouths over the next 50 years." ${ }^{35}$ As noted earlier, genetic engineering can create crop plants that are pest resistant and herbicide tolerant, and fish capable of growing faster than traditional fish. ${ }^{36}$ These technological advances can be beneficial in feeding a vast and growing society. ${ }^{37}$ In fact, GM crops can be modified to carry specific vitamins, such as vitamin $A .{ }^{38}$ Consequently, GM crops modified to carry vitamin $\mathrm{A}$ can potentially reduce malnutrition in countries that have a high rate of occurrence of vitamin A deficiency. ${ }^{39}$

Genetic engineering is a beneficial tool in crop production. ${ }^{40}$ For example, the herbicide glycophosate effectively controls weeds; however, it cannot be used where crops are located because it will kill both crops and

29. Id. at 52. The world did not recognize the "significance of Mendel's experiments" until the twentieth century, years after he performed his experiments. Id. "Once Mendel's publications were rediscovered by geneticists investigating the function and behavior of chromosomes, the implications of his postulates were immediately apparent. He had discovered the basis for the transmission of hereditary traits!" Id.

30. See Henkel, supra note 19.

31. Id.

32. Id.

33. Id.

34. See id.

35. FAO Ethics, supra note 3, at 9.

36. See id. at 3.

37. See generally id.

38. See id. at 24. This procedure was done to rice to make the rice grains "produce betacarotene, which can be converted into vitamin A in the body." Id.

39. See FAO Ethics, supra note 3, at 24. GM crops are not the only answer to malnutrition and vitamin A deficiency, it is just one of the possibilities. See id. Other possibilities include promoting food that is naturally high in vitamin $A$ or food that has been fortified with vitamin A. See id.

40. See KLUG \& CummingS, supra note 6, at 432. 
weeds. ${ }^{41}$ Genetic engineering enables scientists to transfer herbicide resistance traits to plants so that plants exposed to herbicides, such as glycophosate, will survive and only the weeds will die. ${ }^{42}$

\section{GM Detriments}

Although, there are many potential benefits to genetic engineering, the process also has some potential detriments. ${ }^{43}$ It is feared that while genetic engineering could greatly help mitigate issues such as world hunger and malnutrition, those in most need of the technology will not have access. ${ }^{44}$ In fact, the science and technology behind the creation of GM crops is tightly held by a few companies holding the patents and licenses. ${ }^{45}$ Additionally, there is concern about the impact GM products will have on the environment, specifically the effect GM plants will have on native plants. ${ }^{46}$ The safety of consuming GM food products is also a concern for the fear that the GM food product may contain allergens or toxins. ${ }^{47}$

\section{The Coming Attraction - Transgenic Animals}

One of the newest, and perhaps the most controversial form of genetic engineering is the creation of transgenic animals. ${ }^{48}$ Genetic engineering offers the benefit of producing "more and better crops and food animals to feed a continuously growing world population." ${ }^{, 49}$ While traditional breeding techniques can take years to develop a desired animal with a specific trait, genetic engineering can take far less time. ${ }^{50}$ However, the creation behind transgenic animals is not a perfect science. ${ }^{51}$

\section{See id.}

42. See id.

43. See FAO Ethics, supra note 3, at 14.

44. See id. at 17.

45. See id. at 14.

46. See id.

47. See id.

48. See Glossary, supra note 17. Discussion of transgenic animals does not necessarily include a discussion of cloned animals as they are not the same thing. See id. A clone is defined as "[a] group of genes, cells, or organisms derived from a common ancestor. Because there is no combining of genetic material (as in sexual reproduction), the members of the clone are genetically identical to the parent." Id. However, some scientists have turned to cloning "as a way to expand the herd of transgenic animals." Lewis, supra note 5. Researchers that do this will first create the transgenic animal and then use cloning technique "to create replicas of the transgenic animal." Id. This is done because large mammals do not "multiply as plentifully or as rapidly as fish." Id. The transgenic techniques are used to obtain the "desired characteristic in the animal" and cloning is used to "produce a core breeding herd." Id.

49. Lewis, supra note 5.

50. See id.

51. See id. 
To "create" a transgenic animal, scientists first must isolate the specific gene for the trait they want the animal to possess. ${ }^{52}$ In one approach, a scientist will actually inject the transplanted gene into a fertilized egg. ${ }^{53}$ If the egg survives, it is then implanted into a surrogate mother. ${ }^{54}$ However, this process does not guarantee that the offspring will manifest the desired trait. ${ }^{55}$ In fact, only a few of the offspring that live until birth will actually "carry the new gene integrated in such a way that it actually functions." 56 The success rate of gene transfer in animals is low- "usually one or two per cent." 57

In addition to the low success rate of gene transfer, there are other problems with transgenic animals. ${ }^{58}$ For example, it is difficult to predict when and where the gene will be expressed on the animal. ${ }^{59}$ The process of creating transgenic animals is also costly. ${ }^{60}$ In fact, traditional breeding selection programs promote productivity ${ }^{61}$ or cost reduction ${ }^{62}$ where "measurement and recording in herds/flocks is feasible." ${ }^{63}$ The production of transgenic animals, and even genetically modified plants, has caused concern about "potential danger from narrowing of genetic variation" in plants and animals and "decreased resilience in the face of disease ....",64

52. See id. The next step after isolating the gene is to create a "molecular vehicle ... that will carry the gene into the nucleus of the cell and permanently integrate it into the chromosome." Id. Chromosomes carry the genes of an organism. See Glossary, supra note 17. The science behind transgenic fish was discovered by mistake some twenty years ago in Canada when a researcher accidentally froze a fish tank containing flounder. See Lewis, supra note 5. When the tank was finally thawed, the flounder were still alive. See id. The species of flounder in the tank contained a protein with an "on-switch" that acted similar to the way anti-freeze works in a car. See id. Researchers isolated the gene containing the on-switch protein and inserted it into fertilized eggs from a species of "salmon that produces a growthstimulating hormone." Id. This produced salmon that grew faster than the traditional salmon of that species. See id.

53. See Lewis, supra note 5.

54. See id.

55. See id.

56. Id. Those offspring that actually carry a functioning gene can be "multiplied by conventional breeding." Id. Additionally, an animal that carries a functioning gene can become very valuable. See id. For example, the Genzyme Transgenics Corporation in Massachusetts "created a goat that carries the gene for antithrombin III, a blood protein that can prevent blood clotting in people." Id.

57. E.P. CUNNINGHAM, COMMISSION ON GENETIC RESOURCES FOR FOOD AND AGRICULTURE, RECENT DEVELOPMENTS IN BIOTECHNOLOGY AS THEY RELATE TO ANIMAL GENETIC RESOURCES FOR FOOD AND AGRICULTURE at 12, U.N. Doc. CGRFA-8/99/Inf.9 (1999). The low success rate causes great expense for large mammals, such as cows. See id. Therefore, "most work has been done in mice, pigs and sheep." Id.

58. See id.

59. See id.

60. See CUNNINGHAM, supra note 57 , at 12 .

61. See id. Genes promoting productivity include genes that promote meat and milk. See id.

62. See id. Disease resistance is an example of cost reduction genes. See id.

63. Id.

64. Id. at 21 . 
Moreover, the general public appears skeptical about accepting genetically modified animals as a potential food source. ${ }^{65}$ "Experimenting with and altering animals is a less acceptable practice" than experimenting with plants. ${ }^{66}$ This is partially because there are cultural and religious beliefs that prevent some people from consuming food derived from animals. ${ }^{67}$ There is also concern about the ethical issues involved with modifying animals. ${ }^{68}$ Whether or not transgenic animals ultimately enter the marketplace will depend on the individual country and consumer acceptance of novel foods. ${ }^{69}$

\section{The CANADIAN APPROACH}

\section{A. Regulatory Overview}

Canada's regulatory approach to genetically modified organisms (GMOs) "provides for the risk assessment and management of biotechnology products from a sustainable development perspective." In 1993, Canada issued the Federal Regulatory Framework for Biotechnology (Framework), ${ }^{71}$ which was created to form an "efficient" and "effective" regulatory approach towards biotechnology based on six principles. ${ }^{72}$ These six principles balance the benefits of biotechnology "with the need to protect human health, animal health and the environment." ${ }^{\text {"T3 }}$ The Framework provides that novel products

65. See FAO Ethics, supra note 3, at 19-20.

66. Id. at 20.

67. See id.

68. See COMMISSION OF THE EUROPEAN COMMUNITIES, OPINION ON ETHICAL QUESTIONS ARISING FROM THE COMMISSION PROPOSAL FOR A COUNCIL DIRECTIVE ON LEGAL PROTECTION FOR BIOTECHNOLOGICAL INVENTIONS, 1993, at http://europa.eu.int/comm/european_group_ ethics/gaieb/en/opinion3.pdf (last visited Oct. 31, 2003).

69. See Canada's GMOs, supra note 17. See also Transgenic Fish, infra note 205; EU Questions, infra note 228.

70. Gov't of Canada, Response of the Fed. Dep'ts and Agencies to the Petition Filed May 9, 2000 by the Sierra Legal Defence Fund Under the Auditor General Act: Review of Federal Laws, Regulations and Policies on Genetically Modified Organisms (2000), I 9, at http://www.inspection.gc.ca/English/sci/biotech/enviro/sierrae.shtml (last visited Oct. 31, 2003) [hereinafter Response].

71. See generally id. The Federal Regulatory Framework for Biotechnology defines biotechnology as "the application of science and engineering in the direct or indirect use of living organisms in their natural or modified forms." Id. I 15. The Framework finds that "[b]iotechnology is a series of techniques, not a type or class of product." Id. This definition applies to both traditional food products and those products that are developed from "molecular techniques" including genetic engineering. Id.

72. See id.

73. Id. 9 16. The six principles of the Framework:

a. Maintains Canada's high standards for the protection of the health of workers, the general public and the environment;

b. Uses existing legislation and regulatory institutions to clarify responsibilities and avoid duplication;

c. Continues to develop clear guidelines for evaluating products of biotechnology which are in harmony with national priorities and international 
will be regulated under the same regulations as traditional products. ${ }^{74}$ Further, it provides that existing regulations would govern novel products rather than creating new regulations. ${ }^{75}$ It also works to avoid duplication amongst regulatory agencies. ${ }^{76}$ The government regulates these products "in order to protect human, animal and environmental health and to protect consumers against fraud." 77 The regulations set forth by the Canadian government also work to "maintain international quality and safety standards that facilitate trade." 78

Canada allocates the "legislative and regulatory responsibility for health and environmental assessment of biotechnology products" ${ }^{179}$ between the following four agencies: Health Canada ${ }^{80}$ the Canadian Food Inspection Agency (CFIA), ${ }^{81}$ the Department of Fisheries and Oceans (DFO), ${ }^{82}$ and Environment Canada. ${ }^{83}$

Health Canada assesses novel food safety. ${ }^{84}$ CFIA enforces the regulations created by Health Canada. ${ }^{85}$ DFO is responsible for maintaining policies and programs concerning Canada's oceans and bodies of freshwater. ${ }^{86}$ Finally, Environment Canada and Health Canada jointly share responsibilities
standards;
d. Provides a sound scientific database on which to assess risk and evaluate products;
e. Assures both the development and enforcement of Canadian biotechnology regulations are open and include consultation; and
f. Contributes to the prosperity and well-being of Canadians by fostering a favourable climate for investment, development, innovation and adoption of sustainable Canadian biotechnology products and processes.

Id.

74. See Canadian Food Inspection Agency Office of Biotechnology, Regulating Agricultural Biotechnology in Canada: An Overview (2001), at http://www.inspection.gc.ca/ english/sci/biotech/reg/bioage.shtml (last visited Oct. 31, 2003) [hereinafter CFIA Overview].

75. See id.

76. See Response, supra note 70, 919.

77. CFIA Overview, supra note 74.

78. Id.

79. Response, supra note 70, I 28.

80. See generally Response, supra note 70, 91 29-32.

81. See generally id. II 33-34.

82. See generally id. $9135-36$.

83. See generally id. I 37-39. "Pest control products are regulated under the Pest Control Products Act by the Pest Management Regulatory Agency." CFIA OVERVIEW, supra note 74. Canada also has three agencies, Industry Canada, Agriculture and Agri-Food Canada, and Natural Resources Canada, which do not have regulatory power regarding products produced from biotechnology, but play important advisory functions in policy development. See Response, supra note 70, at tbl. 1.

84. See generally Food and Drugs Act, C.R.C., ch. 870, (2002) (Can.).

85. See generally Office of Biotechnology, Canadian Food Inspection Agency, Regulating Agricultural Biotechnology in Canada: Environmental Questions (2001), at http://www. inspection.gc.ca/english/sci/biotech/enviro/envrege.shtml (last visited Oct. 31, 2003) [hereinafter CFIA Envtl. Questions].

86. See Response, supra note 70, $\mathbb{1} 35$. 
to determine whether a substance is or may become toxic before it can be manufactured or imported into Canada. ${ }^{87}$

\section{B. Food Safety Concerns}

Health Canada and CFIA are closely related regulatory agencies. ${ }^{88}$ The CFIA is the primary agency "for regulating agricultural products to assess whether new products are safe to humans, animals and the environment."89 Whereas, Health Canada is responsible for "food safety assessment of novel plants that are developed for use as food, or as animal feed if the modified feed has the potential to introduce harmful components into the portion of the animal being consumed as food." 90

Health Canada derives its regulatory authority for enforcing food safety and nutritional issues from the Food and Drugs Act. ${ }^{91}$ Genetically engineered foods fall under the definition of novel foods in Canada. ${ }^{92}$ In 1999, Health Canada amended the Food and Drugs Act to require pre-market notification ${ }^{93}$ of novel foods. ${ }^{94}$ Pre-market notification allows Health Canada to assess the safety of a novel food prior to the food's introduction in the market place..$^{95}$ Companies wanting to sell a novel food product in Canada must submit information about the novel product to Health Canada. ${ }^{96}$ Health Canada uses this information to determine the safety of the food item. ${ }^{97}$ A company seeking approval of a novel product is not allowed to advertise or sell the product until it has been approved by Health Canada. ${ }^{98}$ Such a regulation helps to protect consumers by preventing novel foods from the marketplace until after a thorough scientific examination is completed. ${ }^{99}$

\section{See id. I 37.}

88. See id. $\$ 33. "CFIA is responsible for enforcing policies with respect to safety and nutritional quality of food sold in Canada, Health Canada is responsible for establishing the standards for these policies and for assessing the effectiveness of the Agency's activities." Id.

89. CFIA Envtl. Questions, supra note 85.

90. Health Canada, Regulatory Impact Analysis Statement (1999), at http://www.hcsc.gc.ca/food-aliment/mh-dm/ofb-bba/nfi-ani/e_regulatory_impact.html (last visited Oct. 31, 2003) [hereinafter Reg Impact Stmt].

91. See generally Food and Drugs Act, C.R.C., ch. 870 (2002) (Can.).

92. See generally Novel Foods Regulations, C.R.C., ch. 870, § B.28.001 (1999) (Can.).

93. See generally id. The pre-market notification requirement is similar to regulations found in the European Union and the United States. See Reg Impact Stmt, supra note 90. As of 1999, the Australia New Zealand Food Authority had also proposed a similar regulation. See id.

94. See Reg Impact Stmt, supra note 90.

95. See id.

96. See id.

97. See id.

98. See id.

99. See id. 
Health Canada considers numerous factors in assessing the safety of a novel food product, ${ }^{100}$ including an "evaluation of the process used to develop [the novel food]; the comparison of its characteristics to that of the traditional counterpart; the nutritional quality and the potential for the presence of any toxicants or anti-nutrients; and the potential allergenicity resulting from any proteins introduced into the food." ensure that the novel food is as safe as other foods found in the market place. ${ }^{102}$ As soon as Health Canada approves a novel food product, that product is eligible to be sold in the market. ${ }^{103}$ The product will then be subjected to the same post-market standards as all food, traditional or novel. ${ }^{104}$ Between 1994 and December of 2000, Health Canada notified the manufacturers of forty-two genetically engineered products that they could release their products into the marketplace. ${ }^{105}$ The majority of the approved genetically engineered products were crop plants "that have been genetically modified to improve agronomic characteristics such as crop yield, hardiness and uniformity, insect and virus resistance; and herbicide tolerance." 106

\section{Environmental Contamination and Concerns}

The Canadian Food Inspection Agency (CFIA) is responsible for federal food inspections, quarantine services, and "plant protection and animal health programs." 107 CFIA's regulatory authority comes from five different acts, "the Seeds Act, the Feeds Act, the Fertilizers Act, the Health of Animals Act and the Plant Protection Act." 108 Like Health Canada, CFIA also performs safety assessments on novel products before they can be used. ${ }^{109}$ This assessment

100. See Health Canada, Question and Answers Food and Drug Amendment-Schedule No. 948, Regulatory Impact Analysis Statement (2000), available at http://www.hcsc.gc.ca/food-aliment/mh-dm/ofb-bba/nfi-ani/e_qa_modification_e.html (last visited Oct. 31, 2003) [hereinafter Schedule No. 948].

101. Id.

102. See id.

103. See id.

104. See id.

105. See id.

106. Schedule No. 948 , supra note 100 . Included in the approved crop plants were "corn, canola, potatoes, and soybean." Id.

107. Response, supra note 70, 9 85. CFIA was created in April of 1997 by The Canadian Food Inspection Act. See id. 133 . It is stressed that CFIA has been organizationally separated "from any part of the government involved in research and development of biotechnology products." Id.

108. CFIA Envtl. Questions, supra note 85. In February 2001, the Canadian government was working to develop new regulatory requirements for four of the Acts (the Seeds Act, the Feeds Act, the Fertilizer Act, and the Health of Animals Act) so that the acts would specifically "address the safety of organisms developed through genetic engineering in the environment." Id.

109. See id. CFIA assesses products such as plants containing novel traits, biofertilizers, livestock feeds and veterinary biologics. See id. 
considers human occupational and food safety as well as "animal and environmental safety." "10 Occasionally, CFIA will also consider the effectiveness of the novel product. ${ }^{111}$ The assessment, like the Health Canada assessment, uses information provided by the developer to identify safety concerns. ${ }^{112}$ An environmental risk assessment is required for "confined field trials" for "plants with novel traits."113 A second environmental assessment "is then required for unconfined release, and if it is to be used as a food or [animal] feed it must then undergo a further safety assessment by Health Canada or CFIA's Feed Section before it may be used for commercial production." 14 Once CFIA deems a novel product safe, in light of the assessment and as compared to its traditional counterpart, the novel product can be released into the environment. ${ }^{15}$

A major concern with genetically engineered agricultural products is outcrossing to a wild species. ${ }^{116}$ Outcrossing is "the potential for genes to move from a genetically engineered plant to a wild relative." 117 The safety assessment required for plants containing novel traits includes an assessment for the potential for the novel trait to "flow"118 to a wild relative. ${ }^{119}$ Most of the plants containing novel traits "that have been approved for release in Canada do not have wild relatives." 120 However, Canada has approved canola plants for commercial release even though they are "known to outcross with other plants of the same species, and can cross with a few related plants of

110. Id.

111. See id.

112. See CFIA Envtl. Questions, supra note 85. In performing the environmental safety assessment, CFIA will take into account the following questions:

- Does the plant have the potential to become a weed of agriculture or to be invasive of natural habitats?

- Is there potential for gene flow to wild relatives whose hybrid offspring may become more weedy or invasive?

- Does the plant have the potential to become a plant pest?

- Is there a potential impact on non-target organisms?

- Is there a potential impact on biodiversity?

- Is there a potential for the development of resistance as a result of the release of this plant?

Id.

113. Id.

114. Id.

115. See id.

116. See Canadian Food Inspection Agency Office of Biotechnology, Outcrossing to Wild Species (2001), at http:// www.inspection.gc.ca/english/sci/biotech/enviro/transfe.shtml (last visited Oct. 31, 2003) [hereinafter Outcrossing].

117. Id.

118. See Glossary, supra note 17. Gene flow is defined as "[t]he movement of genes from one population of a species to another by interbreeding." Id.

119. See Outcrossing, supra note 116. This assessment includes "(1) the potential for gene flow, and (2) the potential impact of gene flow should it occur." Id.

120. Id. 
other species ...."121 CFIA has concluded that gene flow of canola plants is possible, but that it would likely "not result in increased weediness or invasiveness of wild relatives." 122

However, it should be noted, that Canadian courts will not allow outcrossing to be an excuse if genetically modified plants belonging to another person are found growing in someone else's fields. ${ }^{123}$ Specifically, a Canadian court decided a case involving a farmer who had genetically modified canola plants growing in his field. ${ }^{124}$ The farmer had not purchased the genetically modified seeds. ${ }^{125}$ In fact, the farmer argued that the seeds for the genetically modified plants must have been accidentally mixed with the seeds he planted. ${ }^{126}$ He speculated that the seeds "probably blew off a passing truck into one field ...."127 A Canadian court held that a farmer must pay for the genetically modified plants that were found growing in his field. ${ }^{128}$ The judge found that it does not matter how the crops entered the field, the farmer must pay the producer of the plants for the crops. ${ }^{129}$ Even though the judge was not convinced by the farmer's story, he noted that even if the plants entered the farmer's property by accident, the farmer bore the duty to destroy the plants once he realized that they were a genetically modified strain of the plant. ${ }^{130}$

The Department of Fisheries and Oceans (DFO) controls regulations and policies relating to the oceans and freshwater of Canada. ${ }^{131}$ The agency conducts risk assessments concerning applications to grow transgenic fish outside of a "secure containment facility."132 DFO also conducts "research on transgenic aquatic organisms" in an effort to "understand the technology and

121. Id. An example of a plant that canola plants can cross with is Brassica rapa. See id. In canola plants that are herbicide tolerant, "any tolerance genes transferred to wild relatives," the resulting offspring "would only gain a competitive advantage in areas where the herbicide was being used to control weeds." Id. These plants could be controlled by other means than herbicides. See Outcrossing, supra note 116.

122. Id. CFIA has determined that although these particular canola plants may have gene flow, it is unlikely that the gene flow will cause an increase in weeds because there are ways to control these plants. See id.

123. See generally Kurt Kleiner, Victory for Monsanto: If Modified Plants Contaminate Your Crops it Could Cost You Dear, NEW SCIENTIST, Apr. 7, 2001, available at http://www.newscientist.com/hottopics/gm (last visited Oct. 31, 2003).

124. See id. Remember, canola plants were approved for release even though gene flow is possible with the plants. Outcrossing, supra note 116.

125. See Kleiner, supra note 123.

126. See id.

127. Id.

128. See id. See Monsanto Canada Inc. v. Schmeiser, [2001] 3 F.C. 35.

129. See Kleiner, supra note 123 . The judge ordered the farmer to pay Monsanto 15,450 Canadian dollars for the crops that were found growing in his fields. See id.

130. See id. The farmer has counter-sued Monsanto, claiming that environmental contamination from their genetically modified plants forced him to destroy a plant variety that he had been developing for years. See id.

131. See Response, supra note 70, 935.

132. Id. II 36. 
to forecast potential environmental impacts." ${ }^{133}$ However, no transgenic aquatic organisms currently grow outside of secured containment facilities. ${ }^{134}$ Until the DFO creates regulations for genetically engineered aquatic organisms, "all applications for research or commercial development of transgenic fish [aquatic organisms] will be assessed under the New Substance Notification Regulations of the Canadian Environmental Protection Act, and be subjected to the time provisions of these regulations."135 The DFO also "supports research gene banking for populations that are considered valuable." 136

Environment Canada shares responsibility with Health Canada in "assuring that the determination of whether a substance is 'toxic' or capable of becoming 'toxic' occurs from both a human health and environmental point of view before the substance can be manufactured or imported into Canada." 137 Environment Canada obtains its regulatory authority from the Canadian Environmental Protection Act, 1999 (CEPA) ${ }^{138}$ The CEPA "is the key authority for the government to ensure that all new substances are assessed for their potential to harm human health or the environment." ${ }^{139}$ The CEPA covers all transgenic aquatic organisms. ${ }^{140}$ Due to this, DFO and Environment Canada work together to create "a consistent regulatory framework for transgenic aquatic organisms that will meet the criteria set out in CEPA 1999."141

\section{Transgenic Animals}

The ethical acceptability of the application of biotechnology to animals and their use requires an assessment of the effects on the well-being of the animal in relation to potential and actual benefits which may accrue to society. Wellness is more [than] absence of illness. It is the ultimate manifestation of the integration of an animal's internal and external environments. ${ }^{142}$

133. Id.

134. See id.

135. Id.

136. Response, supra note 70, I 57. Gene banks preserve samples of genetic resources. See id. I 56. Agriculture and Agri-Food Canada has "a network of crop gene banks which preserves over 110,000 samples of plant genetic resources for food and agriculture." Id.

137. Response, supra note 70, 9 37. Like CFIA, Environment Canada assures "clear separation of its regulatory work from activities that might create a conflict of interest." Id. I 39.

138. See id. I 37.

139. Env't Canada, Factsheet Regulatory Roadmap for New Substances in Canada (2001), at http://www.ec.gc.ca/ceparegistry/regulations/FINAL-roadmap_e.pdf (last visited Oct. 31, 2003). However, the CEPA also contains a provision exempting substances from its requirements if the substance is regulated by another act. $I d$.

140. See Response, supra note 70, 964.

141. Id.

142. Office of Biotechnology, Canadian Food Inspection Agency, Consultation on Regulating Livestock Animals \& Fish Derived from Biotechnology (2001) I 3, at http://www.inspection.gc.ca/english/sci/biotech/tech/aniconsulte.shtml (last visited Oct. 31, 2003) [hereinafter Transgenic Regulations]. 
Although, currently, no transgenic animals are available for sale in Canada, ${ }^{143}$ the Canadian Government is working to produce regulations that would adequately address transgenic animals intended for use as food. ${ }^{144}$ Agriculture and Agri-Food Canada has stressed the importance of considering "Canada's unique environment" and "regional livestock management practices" alongside those standards that are "being developed globally." 145 Interestingly, Health Canada stated,

[N]umerous animals which either, do not incorporate or lose the novel DNA, or do not express the desired characteristic will be propagated. ${ }^{146}$ In order to recover some of the costs incurred during the development of this technology as well as reduce disposal costs, non-transgenic livestock and fish may be sold for food. ${ }^{147}$

If and when transgenic livestock and fish are approved as a food source in the future, they would be regulated by Health Canada under the Novel Food Regulations. ${ }^{148}$

The Canadian Government has worked to develop regulations that "are consistent with those of recognized international scientific groups and with other national governments." 149 This is done, in part, to ensure safety of novel products and to help facilitate international trade. ${ }^{150}$ In fact, Canada has a

143. See generally Canada's GMOs, supra note 17.

144. See generally Transgenic Regulations, supra note 142.

145. Id. II 3.

146. Id. This is because "[m]ethods presently used to genetically modify livestock animals and fish are inefficient and their stability within the recipient genome is unknown." Id.

147. Id.

148. See Department of Fisheries and Oceans, Fisheries \& Oceans Response to the Interim Report of the Standing Senate Committee on Fisheries Entitled "Aquaculture in Canada's Atlantic and Pacific Regions," available at http://www.dfo-mpo.gc.ca/communic/reports/ aquaculture/response-reponse_e.htm (last visited Oct. 31, 2003). Under the Food and Drug Act, anyone who wants to sell or advertise transgenic animals for food use will have to follow the pre-market notification requirements as required under the Novel Food Regulations. See Transgenic Regulations, supra note 142.

149. Canadian Food Inspection Agency Office of Biotechnology; Biotechnology, Agriculture and Regulation (2001), at http://www.inspection.gc.ca/english/sci/biotech/reg/ bare.shtml (last visited Oct. 31, 2003).

150. See id. CFIA product evaluators "developed regulatory directives that are consistent with those used by international authorities." Id. Included in those Canadian directives are the following principles:

1. To build on current legislation where possible, rather than creating new legislation to govern new products which are developed.

2. To focus on product characteristics, rather than the method of production. At the present time, all products developed through genetic engineering (recombinant products) are assessed for unintended effects that may result from the introduction of foreign genes or DNA sequences. 
"science-based regulatory system" that "is in line with principles laid out by organizations such as the World Health Organization (WHO), the Organization for Economic Cooperation and Development (OECD), and the Food and Agriculture Organization (FAO)." types of genetic modification in crops."152

\section{THE UNITED STATES APPROACH}

\section{A. Overview}

In the United States, there are three main agencies responsible for regulating and overseeing GM food products. ${ }^{153}$ The United States Department of Agriculture (USDA) regulates GM products including plant pests, ${ }^{154}$ plants, and veterinary biologics. ${ }^{155}$ The Environmental Protection Agency (EPA) regulates products that are "microbial/plant pesticides, new uses of existing pesticides, novel microorganisms." 156 Finally, the Food and Drug Administration (FDA) regulates products that are used as "food, feed, food additives, veterinary drugs, human drugs and medical devices." ${ }^{157}$ Many GM food products will ultimately be regulated by one or more of these agencies and potentially by all three regulatory agencies. ${ }^{158}$ For example, GM corn that is modified for herbicide tolerance will be regulated by the USDA to ensure

3. To conduct evaluations for each product on the basis of its unique characteristics and to establish appropriate safety levels based on the best scientific information. Safety is defined, not as the complete absence of risk, but rather as the level of "acceptable risk." If the risk is not acceptable, the application will be refused.

Id.

151. Response, supra note 70, at Forward. Canada's regulatory system for products of biotechnology includes stiff penalties and "potential jail terms" for those that violate the regulations. See id. $\mathbb{1}$ 75. Indeed, Canada considers itself a world leader determining international policy concerning genetically engineered products. See id. Specifically, Canada has been helping to shape international policy concerning labeling of genetically modified organisms (GMOs). See id.

152. Canada's GMOs, supra note 17. Included in the approved GM crops are corn, canola, potatoes, tomatoes, squash, soybean, flax, cottonseed oil, and sugar beet. See id. The different types of modifications include pest resistance, herbicide tolerance, and slow-ripening traits. See id.

153. See U.S. Department of Agriculture, United States Regulatory Oversight in Biotechnology Responsible Agencies—Overview, at http://www.aphis.usda.gov/brs/usregs.html (last visited Oct. 31, 2003) [hereinafter U.S. Regulatory Oversight].

154. See id. Included in the plant pests regulated by USDA are transgenic arthropods and transgenic invertebrates. See U.S. Department of Agriculture, Regulation of Transgenic Arthropods, and Other Transgenic Invertebrate Plant Pests, at http://www.aphis.usda.gov/brs/ arthropod/ (last visited Oct. 31, 2003) [hereinafter Arthropods].

155. See U.S. Regulatory Oversight, supra note 153.

156. Id.

157. Id.

158. See generally id. 
that the product is safe to grow. ${ }^{159}$ The EPA will regulate the GM corn product under its pesticide law. ${ }^{160}$ Finally, the FDA will ensure the GM corn food product is safe for human consumption. ${ }^{161}$

\section{B. Food Safety}

The FDA ensures that novel food products are just as safe as traditional food products. ${ }^{162}$ The FDA's regulatory policy for biotechnology is based on existing food law. ${ }^{163}$ The Federal Food, Drug, and Cosmetic Act (FFDCA) ${ }^{164}$ creates a legal obligation for companies that sell any food. Whether it is a conventional food product or a novel food product, all food products offered for sale in the United States must meet the safety standards provided by the law. ${ }^{165}$

The FDA also has a consultative process for producers of genetic engineered foods. ${ }^{166}$ FDA considers the consultative process important. ${ }^{167}$ Thus, the producers work closely with the FDA in determining the safety of the bioengineered product. ${ }^{168}$ The process allows FDA to be aware of food products containing GM organisms before the product is released commercially so that FDA can address "questions regarding the safety, labeling, or regulatory status of the food or food ingredient." 169 The consultative process requires producers to provide the FDA with documentation showing that the specific GM food product is as safe as the traditional food product. ${ }^{170}$ The documentation will address issues with the actual gene(s) used in the GM food product, such as whether the gene(s) is from a "commonly allergic plant, the characteristics of the proteins made by the genes, their biological function, and how much of them will be found in the food."171 FDA scientists then review

159. See id.

160. See id.

161. See U.S. Regulatory Oversight, supra note 153.

162. See Henkel, supra note 19.

163. See U.S. Regulatory Oversight, supra note 153.

164. Federal Food, Drug, and Cosmetic Act, 21 U.S.C. $\$ 301$ (2002). This act sets forth the requirements for food, drugs, and cosmetics in the United States. See id.

165. See Thompson, supra note 27.

166. See id. This process was voluntary at the time the Thompson article was written. See generally id. However, since then the FDA has proposed regulations that would mandate this process. See Pre-market Notice Concerning Bioengineered Foods, 66 Fed. Reg. 4706 (Jan. 18, 2001) (to be codified at 21 C.F.R. $\S \S 192,592$ ). It is interesting to note, that although this was a voluntary process, FDA believes that all genetically engineered foods available in the United States marketplace have gone through the consultative process prior to being marketed. See id.

167. See Thompson, supra note 27.

168. See 66 Fed. Reg. 4706 , at 4707 . This process is similar to the pre-market notification requirements found in Canada. See generally Novel Foods Regulations, C.R.C., ch. $870, \S$ B.28.001 (1999) (Can.).

169. 66 Fed. Reg. 4706 , at 4707 . Under the proposed rule, a developer of bioengineered food must "submit a scientific and regulatory assessment of the bioengineered food 120 days before the bioengineered food is marketed." Completed Consultations, supra note 13.

170. See Thompson, supra note 27.

171. Id. 
the supplied information and begin to formulate questions for the producer to answer. ${ }^{172}$ The overall process usually takes at least one year to complete. ${ }^{173}$

Altering food products through biotechnology presents an array of regulatory issues for the FDA to consider. ${ }^{174}$ FDA must consider whether the food, in its modified state, is now a food additive, adulterated, or misbranded. ${ }^{175}$ The FDA does not consider genetically added food traits a food additive. ${ }^{176}$ Prior to marketing, the FDA must approve all food additives, ${ }^{177}$ unless the substance is not "generally recognized as safe (GRAS)." 178 FDA also fears that the use of rDNA technology in "plant breeding may lead to unintended changes in foods that raise adulteration or misbranding questions." 179 Adulteration is an important fear as adulterated food can cause serious health problems for people with food allergies. ${ }^{180}$ Misbranding also raises concerns for consumers. ${ }^{181}$ For example, biotechnology can "modify a soy plant so that the composition of oil derived from the plant would more closely resemble that of a tropical oil than that of conventional soy oil." 182 If the manufacturer labeled this food product "soy oil" it would not adequately describe the product because the modified food product is "significantly different from what is customarily understood to be "soy oil.","183

The FDA started the consultative process because people that produce food through genetic engineering have a greater potential to develop foods that present legal issues, such as misbranding and adulteration issues, than those breeders that develop food "using traditional or other breeding techniques." 184 Between August 12, 1991, and February 25, 2002, the FDA completed approximately fifty-three consultations on bioengineered foods, including corn, rice, canola, soybeans, tomatoes, potatoes, papaya, and cantaloupe. ${ }^{185}$

\author{
172. See id. \\ 173. See id. \\ 174. See 66 Fed. Reg. 4706 , at 4709. \\ 175. See id. \\ 176. See 21 C.F.R. $\$ \S 321(s), 201(s)$. \\ 177. See id. \\ 178. 66 Fed. Reg. 4706 , at 4709. \\ 179. Id. at 4710 .
}

180. See 66 Fed. Reg. 4706 , at 4710 . Adulterated food can be a problem for people with food allergies as they may unknowingly consume a food product containing an allergen. See id. Adulterated food can have an "[a]bsence, substitution, or addition of constituents." Federal Food, Drug, and Cosmetic Act, 21 U.S.C. § 342(b) (1996).

181. See generally 66 Fed. Reg. 4706 , at 4710 . A food is considered misbranded if it has a "[f]alse or misleading label ... [o]ffer[ed] for sale under another name" or if it is an imitation of some other food product. 21 U.S.C. $\S 343$ (2002).

182. 66 Fed. Reg. 4706 , at 4710

183. Id.

184. Id. at 4711.

185. See generally Completed Consultations, supra note 13. In the context of this source, bioengineered foods are "foods derived from plant varieties that are developed using rDNA technology." Id. The listed foods were genetically altered for a variety of traits including herbicide tolerance, delayed ripening, fertility restorer, pest resistance, and male sterility. See id. 


\section{Environmental Concerns}

The Animal and Plant Health Inspection Service (APHIS), a division of the USDA, is responsible for the "agricultural environmental safety of planting and field testing genetically engineered plants." ${ }^{186}$ APHIS obtains its regulatory authority through the Federal Plant Pest Act. ${ }^{187}$ The Federal Plant Pest Act "provide[s] procedures for obtaining a permit or for providing notification, prior to 'introducing' a regulated article in the United States." 188

In addition, APHIS has the authority to regulate genetically engineered plants through the Genetically Engineered Organisms Regulation (GEOR). ${ }^{189}$ The GEOR allows APHIS to regulate most genetically engineered regulated plants under a "notification procedure." 190 This regulation applies to the introduction "of genetically engineered organisms and products that are derived from known plant pests." that prior to introduction, the company wanting to introduce a regulated genetically engineered plant would either have to notify APHIS or secure a permit through APHIS. ${ }^{192}$ A producer can petition to receive unregulated status under the Federal Plant Pest Act. ${ }^{193}$ Once unregulated status is granted to a product, "the product (and its offspring) no longer requires APHIS review for movement or release in the U.S."194

The EPA works to ensure that biologically produced pesticides are safe. ${ }^{195}$ The EPA regulates pesticide safety through the Office of Pesticide Programs, whose authority derives from the Federal Insecticide, Fungicide, and Rodenticide Act (FIFRA). ${ }^{196}$ EPA also uses the FFDCA to set tolerance levels for pesticide products "on and in food and feed, or establishes an exemption from the requirement of a tolerance." act under the authority of the Toxic Substance Control Act to regulate "microorganisms intended for commercial use that contain or express new combinations of traits." 198

186. Thompson, supra note 27.

187. See U.S. Regulatory Oversight, supra note 153.

188. Id.

189. See Genetically Engineered Organisms and Products; Simplification of Requirements and Procedures for Genetically Engineered Organisms, 7 C.F.R. $§ 340$ (May 2, 1997).

190. Id.

191. Id.

192. See id.

193. See U.S. Regulatory Oversight, supra note 153.

194. Id.

195. See id. The EPA also ensures the safety of pesticides that are chemically produced. See id.

196. See id. See also Federal Insecticide, Fungicide, and Rodenticide Act, 7 U.S.C. $\$ 136$ (2002).

197. U.S. Regulatory Oversight, supra note 153.

198. Id. 
The Toxic Substance Control Act is designed to "ensure that [the] EPA can adequately identify and regulate risk associated with microbial products of biotechnology without unnecessarily hampering" the biotechnology industry. ${ }^{199}$ New microorganisms ${ }^{200}$ are subject to the "Microbial Products of Biotechnology: Final Regulations Under the Toxic Substance Control Act (Microbial Biotech Regulations)." ${ }^{201}$ The Microbial Biotech Regulations apply to two categories. ${ }^{202}$ The first category is " [b]iotechnology research and development activities involving commercial funds." 203 The second category is "commercial biotechnology products." 204

\section{Transgenic Animals}

The United States has not approved any transgenic animals to enter the food supply. ${ }^{205}$ However, a limited number of transgenic animals have been approved for use as components in animal feed. ${ }^{206}$ The FDA Center for Veterinary Medicine ${ }^{207}$ is the agency in charge of regulating, "in whole or in part, diverse animal biotechnology products."208 The FDA Center for Veterinary Medicine obtains its regulatory authority concerning transgenic animals from the animal drug provisions of the FFDCA. ${ }^{209}$ However, the authority of the FDA Center for Veterinary Medicine "best fit[s] transgenic animals that have

199. U.S. Environmental Protection Agency, Microbial Products of Biotechnology: Final Regulations Under the Toxic Substances Control Act Summary (Fact Sheet), available at http://www.epa.gov/opptintr/biotech/fs-001.htm (last visited Oct. 31, 2003) [hereinafter EPA, Fact Sheet].

200. See id. New microorganisms are "those formed by deliberate combinations of genetic material from organisms classified in different taxonomic genera." Microbial Products of Biotechnology; Final Regulations Under the Toxic Substance Control Act; 40 C.F.R. $\$ \S 700,720$, 721, 723, 725 (1997).

201. EPA, Fact Sheet, supra note 199. See generally Microbial Products of Biotechnology; Final Regulations Under the Toxic Substance Control Act; 40 C.F.R. $\$ \$ 700,720,721,723,725$ (1997).

202. See Microbial Products of Biotechnology; Final Regulations Under the Toxic Substance Control Act; 40 C.F.R. $\$ \S 700,720,721,723,725$ (1997).

203. Id. Examples of this category are, "Persons conducting commercial research using intergeneric microorganisms for biofertilizers; biosensors; biotechnology reagents; commodity or specialty chemical production; energy applications; waste treatment or pollutant degradation; and other TSCA subject uses." Id.

204. Id. Examples of this category include, "Persons manufacturing, importing or processing products for commercial purposes intergeneric microorganisms for biofertilizer; biosensors; biotechnology reagents." Id.

205. See U.S. Food and Drug Administration Center for Veterinary Medicine, Information for Consumers: Questions and Answers about Transgenic Fish, at http://www.fda.gov/cvm/ index/consumer/transgen.htm (last visited Oct. 31, 2003) [hereinafter Transgenic Fish].

206. See id.

207. See id. The Center for Veterinary Medicine "serves as a consulting group to the other FDA Centers" for all types of animals, both traditional and GM, "in the food and feed safety evaluation[s]." Id.

208. Id.

209. See Transgenic Fish, supra note 205. 
agronomic traits now being investigated and developed."210 It is possible, and indeed probable, that other transgenic animals will be modified in ways that "could be viewed as containing food additives, color additives, and vaccines." 211 The FDA will regulate transgenic animals, as either food or pharmaceuticals, just as it does any food or drug that a company wants to market. ${ }^{212}$ This includes "clinical trials that demonstrate safety and effectiveness." 213

Currently, many researchers are studying transgenic fish as a potential food source. ${ }^{214}$ Thus, transgenic fish can be found in laboratories throughout the United States and the world. ${ }^{215}$ Transgenic fish are being researched with the goal of "adding agronomically important traits, like improved growth rates and disease resistance," to common food fish species. ${ }^{216}$ These fish would be advantageous for a fish farmer to raise, as modified fish cost less to raise than traditional fish. ${ }^{217}$ The modified fish cost less money to raise because "it takes less feed and about half the time to produce a crop they can send to market."218 Like other transgenic animals, transgenic fish will also have to garner premarket approval through FDA Center for Veterinary Medicine prior to being released into the marketplace. ${ }^{219}$

Nonetheless, there is concern about outcrossing with transgenic fish. ${ }^{220}$ Scientists warn of possible risks to native fish populations if transgenic fish escape the laboratory and enter the wild. ${ }^{221}$ They fear that if transgenic fish escape into the wild, they may "damage native populations, even to the point of extinction."222

The United States has new regulations that specifically address genetically engineered products. However, the United States in a larger part relies on existing regulations to control genetically engineered products. ${ }^{223}$ The FDA

210. Id.

211. Id.

212. See Lewis, supra note 5.

213. Id.

214. See Transgenic Fish, supra note 205.

215. See id. Different species of salmon and channel catfish are examples of the fish that are being researched. See id.

216. Id.

217. See Lewis, supra note 5.

218. Id.

219. See Transgenic Fish, supra note 205.

220. See Lewis, supra note 5.

221. See id. The USDA funded a study on genetically engineered fish. See id. The scientists involved in this study found reason to believe that transgenic fish could cause harm to native fish populations. See id.

222. Id.

223. See generally Arthropods, supra note 154. The Federal Plant Protection Act, which went into effect in June of 2000 , allows for the release of transgenic organisms including transgenic arthropods, and other invertebrates. See id. Other examples of regulation specifically dealing with genetically modified products are: Genetically Engineered Organisms and Products; Notification Procedures for the Introduction of Certain Regulated Articles; and Petition for Nonregulated Status, 58 Fed. Reg. 17,044 (Mar. 31, 1991) (to be codified at 7 C.F.R. pt. 340), and Microbial Products of Biotechnology; Final Regulation Under the Toxic 
in particular, focuses on how the new GM food product compares and meets "the same safety standards as traditional foods."224

\section{THE EUROPEAN UNION'S APPROACH TO GM PRODUCTS}

\section{A. Regulatory Overview}

The European Union (EU), ${ }^{225}$ through the European Commission, "226 "has developed a broad legislative framework to ensure that GMOs and GMOderived products that are grown, marketed and imported meet the highest standards of safety for the environment, as well as for human and animal health."227 The European Union takes a more skeptical approach to genetically engineered food products and crop plants. ${ }^{228}$ In fact, the European Union has only authorized two GM plants for use in food products. ${ }^{229}$ Unlike Canada and the United States, the European Union is comprised of Member States. ${ }^{230}$ The European Union enacts GMO laws and regulations, but Member States enforce them through their own regulatory agencies. ${ }^{231}$ However, in January 2002, the European Food Safety Authority ${ }^{232}$ was created to encourage cooperation with

Substances Control Act, 62 Fed. Reg. 17,910 (Apr. 11, 1997) (to be codified at 40 C.F.R. pts. $700,720,721,723,725)$. Acts such as the Federal Food, Drug, and Cosmetic Act and the Federal Insecticide, Fungicide, and Rodenticide Act have statements of policy on how to regulate certain GM products that fall under the specific Act. See generally U.S. Regulatory Oversight, supra note 153.

224. Lewis, supra note 5.

225. See generally Europa-The European Union On-Line, the European Union at a Glance, Overview, at http://www.europa.eu.int/abc/index_en.htm (last visited Oct. 31, 2003) [hereinafter Europa]. Currently there are fifteen members in the EU. See id. The fifteen member states are Belgium, Denmark, Germany, Greece, Spain, France, Ireland, Italy, Luxembourg, the Netherlands, Austria, Portugal, Finland, Sweden, and the United Kingdom. See id. There are also several other candidate countries. See id.

226. See GMO Food and Environment Sector, available at http://biotech.jrc.it/home.asp (last visited Oct. 31, 2003) [hereinafter GMO Food Sector]. The European Commission "is at the core of the European Union's policy making process and has no equivalent in the U.S. government." Terence P. Stewart \& David Johanson, Policy in Flux: The European Union's Laws on Agricultural Biotechnology and Their Effects on International Trade, 4 DRAKE J. AGRIC. L. 243, 252 (1999).

227. GMO Food Sector, supra note 226.

228. See Commission Press Room, Questions and Answers on the Regulation of GMOs in the EU (2002), available at http://europa.eu.int/comm/dgs/health_consumer/library/ press/press298_en.pdf (last visited Oct. 31, 2003) [hereinafter EU Questions].

229. See The European Commission, Authorisation, available at http://europa.eu.int/ comm/food/fs/gmo/gmo_legi_authorise_en.html (last visited Oct. 28, 2002) [hereinafter Authorisation] (copy on file with Indiana International \& Comparative Law Review office).

230. See generally Europa, supra note 225.

231. See generally id.

232. See Regulation (EC) No 178/2002 of the European Parliament and of the Council of 28 January 2002 Laying Down the General Principles and Requirements of Food Law, Establishing the European Food Safety Authority and Laying Down Procedures in Matters of Food Safety, 2002 O.J. (L 31) 1, 4 [hereinafter Regulation 178/2002]. 
the Member States in the exchange of information and to "minimise the potential for diverging scientific opinions." 233 The European Food Safety Authority "establishes common principles and responsibilities" and provides a "strong science base" to use in making food safety decisions throughout the Member States. ${ }^{234}$ The European Food Safety Authority will hopefully help consolidate food regulation in the European Union. ${ }^{235}$

The main regulation addressing genetically engineered products in the EU is Directive 2001/18/EC. ${ }^{236}$ Directive 2001/18/EC went into effect on October 17, 2002, creating a case-by-case assessment process. ${ }^{237}$ The assessment process occurs, "before any GMO or product consisting of or containing GMOs, such as maize, tomatoes, or microorganisms can be released into the environment or placed on the market."238 This risk assessment determines the safety risks to health and the environment. ${ }^{239}$ Food products derived from genetically modified foods, "such as paste or ketchup from a GMO tomato" are regulated as novel foods under Regulation (EC) 258/97. 240

\section{B. Food Safety Concerns}

Regulation of GM food products falls under the EU's Novel Foods Regulation. ${ }^{241}$ Foods that were commercially available in at least one Member

\section{Id. 14.}

234. Id. II 6.

235. See generally id.

236. See EU Questions, supra note 228. Prior to Directive 2001/18/EC, Council Directive 90/220/EEC was the main law regarding products produced from genetic engineering. See id. Council Directive 90/220/EEC was repealed by Directive 2001/18/EC. See id. A Council Directive means that the member states must "conform their laws to certain objectives established by the European Union," whereas a decision concerns "specific legislative issues and are binding upon those to whom the decisions are addressed, which may be member states, businesses, or individuals." Stewart \& Johanson, supra note 226, at 255-56.

237. See EU Questions, supra note 228.

238. Id.

239. See id.

240. Id.

241. See Regulation (EC) No 258/97 of the European Parliament and of the Council of 27 January 1997 Concerning Novel Foods and Novel Food Ingredients, 1997 O.J. (L 43) 1. The European Union has six different categories of novel foods, they are:

- $\quad[F] o o d s$ and food ingredients containing or consisting of genetically modified organisms (GMOs) within the meaning of Council Directive 90/220/EEC of 23 April 1990 on the deliberate release into the environment of genetically modified organisms ... ;

- foods and food ingredients produced from, but not containing GMOs;

- foods and food ingredients with a new or intentionally modified primary molecular structure;

- food and food ingredients consisting of or isolated from microorganisms, fungi or algae;

- foods and food ingredients consisting of or isolated from plants and food ingredients isolated from animals, except for food and food ingredients obtained by traditional propagating or breeding practices and having a history of safe food use; 
State prior to May 15, 1997, when the Novel Foods Regulation became active, do not fall under the Novel Foods Regulation. ${ }^{242}$ The Novel Food Regulation contains rules for the "authorisation and labelling of novel foods including food products containing, consisting or produced from GMOs." 243 In order for a food product to fall under the Novel Foods Regulation, a food product must not "present a danger for the consumer . . . mislead the consumer . . . [or] differ from foods or food ingredients which they are intended to replace to such an extent that their normal consumption would be nutritionally disadvantageous for the consumer."244

An applicant who wants to place a novel food into the marketplace must provide enough information to a Member State to enable that State to adequately decide the safety of the applicant's food product. ${ }^{245}$ The Member State then assesses the proposed food product and forwards the assessment to the European Commission, which in turn seeks comments and objections from Member States. ${ }^{246}$ Article 12 of the Novel Foods Regulation allows for Member States to restrict an approved novel food from the Member State's jurisdiction if the Member State feels that the food product "endangers human health or the environment."247 Only " $t]$ wo genetically modified plants, a variety of soybean and a variety of maize" have been authorized "for use in food" in the European Union. ${ }^{248}$ However, the European Union has authorized "[s] everal products derived from GMOs such as flour, starch or oil from a GM maize ... to be placed on the market following a notification to the Commission." 249

- foods and food ingredients to which has been applied a production process not currently used, where that process gives rise to significant changes in the composition or structure of the foods or food ingredients which affect their nutritional value, metabolism or level of undesirable substances.

The European Commission, Food Safety: from the Farm to the Fork-Novel Foods Regulation, available at $\mathrm{http}: / /$ europa.eu.int/comm/food/fs/novel_food/nf_regulation_en.html (last visited Oct. 31, 2003) [hereinafter EU Novel Foods Regulations].

242. See The European Commission, Food Safety: from the Farm to the Fork-Novel Foods, available at http://europa.eu.int/comm/food/fs/novel_food/nf_index_en.html (last visited Oct. 31, 2003) [hereinafter EU Novel Foods].

243. Authorisation, supra note 229.

244. Regulation (EC) No 258/97 of the European Parliament and the Council of 27 January 1997 Concerning Novel Foods and Novel Food Ingredients, 1997 O.J. (L 043) 1, at 13.

245. See generally id.

246. See generally id.

247. Id.

248. EU Questions, supra note 228. There is some confusion as to whether the European Union has approved two or three GM products of food origin as the same source says the Scientific Committee of Food "has issued 3 favourable opinions on food of plant origin (tomato and maize)" and later says, "[t]wo genetically modified plants, a variety of soybean and a variety of maize have been authorised ... prior to the entry of the Novel Foods Regulation" and that no products containing live GMOs have been authorized under the Novel Foods Regulation. Id. 
On January 28, 2002, the European Union adopted legislation authorizing the creation of a European Food Safety Authority (EFSA). ${ }^{250}$ EFSA was formed to "provide independent scientific advice on all matters with a direct or indirect impact on food safety."251 The European Commission envisioned the EFSA as the "scientific point of reference for the whole Union" in order to maintain a "high level of consumer health protection," and thus "help to restore and maintain consumer confidence." ${ }^{252}$ The primary goal of EFSA is direct communication with the public. ${ }^{253}$ EFSA will be able to give scientific advice on GMO products, both food and non-food GM products. ${ }^{254}$ In fact, EFSA will be able to "cover all stages of production and supply, from primary production, animal feed, right through to the supply of food to consumers."255

\section{Environmental Concerns}

The main law regulating GM products that are to be released into the environment is Directive 2001/18/EC. The Directive requires an environmental risk assessment to determine the "risks to human health and the environment before any GMO or product consisting of or containing GMOs . . . can be released into the environment." ${ }^{, 256}$ Environmental risk assessment is defined as "the evaluation of risks to human health and the environment, whether direct or indirect, immediate or delayed, which the deliberate release or the placing on the market of GMOs may pose."257 The objective of an environmental risk assessment is to "identify and evaluate potential adverse effects of

250. See About the European Food Safety Authority, at http://www.efsa.eu.int/about_en .html (last visited Oct. 31, 2003) [hereinafter EFSA]. The creation of the European Food Safety Authority was called for in the White Paper on Food Safety. Commission of the European Communities, White Paper on Food Safety, COM(2000)719 final of Jan. 12, 2000, at 3 [hereinafter White Paper]. The creation of a European Food Safety Authority was a high priority for the European Commission; they felt it was necessary to create such an authority in order to "guarantee a high level of food safety." Id. The legislation behind the creation of the EFSA was Regulation (EC) No 178/2002 of the European Parliament and of the Council of 28 January 2002 Laying Down the General Principles and Requirements of Food Law, Establishing the European Food Safety Authority and Laying Down Procedures in Matters of Food Safety. See Regulation 178/2002, supra note 232.

251. EFSA, supra note 250. EFSA is mainly responsible to report to the European Commission, although it can also report to the European Parliament and the Member States. See id.

252. White Paper, supra not 250 , at 5.

253. See id. at 4.

254. See id. It was a goal of the European Commission to set up an independent authority along with other legislation so that all aspects of food products would be covered from "farm to table." Id. at 3.

255. Id.

256. Id. See also EU Questions, supra note 228.

257. See also Commission Decision of 24 July 2002 Establishing Guidance Notes Supplementing Annex II to Directive 2001/18/EC of the European Parliament and of the Council on the Deliberate Release into the Environment of Genetically Modified Organisms and Repealing Council Directive 90/220/EEC, 2002 O.J. (L 200) 22. 
the GMO . . . on human health and the environment which the deliberate release or placing on the market of GMOs may have."258 The assessment must carefully analyze "[p]ossible interactions with other organisms, including other GMOs ... taking into account the complexity of multitrophic interactions."259 There is a potential that "if biological fitness is enhanced by the genetic modification, the GMO may invade new environments and replace existing species." 260 The environmental risk assessments should be reviewed on a regular basis to consider any new relevant information. ${ }^{261}$ As of November 17,2003 , only sixteen assessed GM plants have been approved for release in the European Union. ${ }^{262}$

The European Environment Agency found that genetically modified crops could safely coexist with traditional crops as long as they are kept far enough apart to avoid cross-pollination. ${ }^{263}$ Plants needing "extra isolation from GM crops include those grown solely to supply high-quality seeds."264 "High-yielding 'male-sterile' varieties of oilseed rape" are also at risk of crosspollination. ${ }^{265}$ The European Union has only approved "the commercial release of 18 GMOs" "[s]ince Directive 90/220/EEC entered into force."266

\section{Transgenic Animals}

Like Canada and the United States, the European Union has not approved any transgenic animals to enter into the food supply. ${ }^{267}$ Currently,

258. Id.

The [environmental risk assessment] has to take into account the relevant technical and scientific ... characteristics of :

- $\quad[T]$ he recipient or parental organism(s),

- [T]he genetic modification(s), be it inclusion or deletion of genetic material, and the relevant information on the vector and the donor,

- $\quad$ TThe GMO,

- [T]he intended release or use including its scale,

- $\quad[T]$ he potential receiving environment, and

- $\quad[\mathrm{T}]$ he interaction between these.

Id.

259. Id.

260. Id.

261. See id.

262. See EU Questions, supra note 228. The Scientific Committee on Plants "issued opinions on applications for the placing on the market of $17 \mathrm{GM}$ plant varieties under Directive 90/220/EEC." Id. The Scientific Committee on Plants issued one unfavorable opinion "due to an insufficient risk assessment in terms of the presence of a number of uncharacterised genes (and particularly) the gene which confers resistance to ... a clinically important antibiotic." Id.

263. See Andy Coghlan, Up to Their Necks in it: Agricultural Biotechnology Firms have Landed in a Legal Mire, NEW SCIENTIST, Aug. 1, 1998, available at http://www.newscientist .com/hottopics/gm (last visited Oct. 31, 2003).

264. Id.

265. Id.

266. EU Questions, supra note 228.

267. See id. 
the European Union does not have legislation specifically addressing transgenic fish. ${ }^{268}$ However, the European Commission has recognized the need for specific legislation focusing on transgenic fish. ${ }^{269}$ Concern exists that transgenic fish in laboratories may escape, finding their way into wild fish populations and ultimately harming the wild fish population. ${ }^{270}$

The European Union takes a strong approach in regulating GM products. ${ }^{271}$ It has established regulations specifically focusing on GM products. ${ }^{272}$ The European Union has approved relatively few GMOs or products containing GMOs for release in either the market place or the environment. ${ }^{273}$ The European Union appears to be taking a cautious approach to novel foods and to biotechnology. ${ }^{274}$

\section{A COMPARATIVE ANALYSIS OF CANADA, THE UNITEd STATES, AND THE EUROPEAN UNION}

Canada, the United States, and the European Union have established different regulatory approaches to products produced through genetic engi-

268. See Communication from the Commission to the Council and the European Parliament: A Strategy for the Sustainable Development of European Aquaculture, $\operatorname{COM}(2002) 511$ final of Sept. 19, 2002, at 22. Currently, there is no legislation addressing transgenic animals in general.

269. See id.

270. See id. See also Lewis, supra note 5.

271. See generally Regulation (EC) No 178/2002 of the European Parliament and of the Council of 28 January 2002 Laying Down the General Principles and Requirements of Food Law, Establishing the European Food Safety Authority and Laying Down Procedures in Matters of Food Safety, 2002 O.J. (L 31) 1. See also Regulation (EC) No 258/97 of the European Parliament and of the Council of 27 January 1997 Concerning Novel Foods and Novel Food Ingredients, O.J. (L 43) 1. See also Commission Decision of 24 July 2002 Establishing Guidance Notes Supplementing Annex II to Directive 2001/18/EC of the European Parliament and of the Council on the Deliberate Release into the Environment of Genetically Modified Organisms and Repealing Council Directive 90/220/EEC, 2002 O.J. (L 200) 22.

272. See EU Questions, supra note 228. In fact, the European Union also has specific legislation (Council Directive 90/679/EEC) in place to protect workers "from risks related to exposure to biological agents" which also includes GMOs. Id. The European Union has strict legislation on labeling requirements for food containing GMOs. Id. Food additives and flavorings also have to be labeled if "DNA or protein of GMO origin is present in the final product." Id.

273. See id.

274. See generally Regulation (EC) No 178/2002 of the European Parliament and of the Council of 28 January 2002 Laying Down the General Principles and Requirements of Food Law, Establishing the European Food Safety Authority and Laying Down Procedures in Matters of Food Safety, 2002 O.J. (L 31) 1. See also Regulation (EC) No 258/97 of the European Parliament and of the Council of 27 January 1997 Concerning Novel Foods and Novel Food Ingredients, 1997 O.J. (L 43) 1. See also Commission Decision of 24 July 2002 Establishing Guidance Notes Supplementing Annex II to Directive 2001/18/EC of the European Parliament and of the Council on the Deliberate Release into the Environment of Genetically Modified Organisms and Repealing Council Directive 90/220/EEC, 2002 O.J. (L 200) 22. 
neering. ${ }^{275}$ While Canada and the United States take similar, albeit not identical, approaches concerning genetically engineered food, the European Union's stance on such food products is dramatically different. ${ }^{276}$ In fact, Canada and the United States have an unprecedented bilateral agreement on agricultural biotechnology. ${ }^{277}$

Canada and the United States forged their agreement in 1998 with the intent to "compare and harmonize" the regulatory process and pre-market assessments of GM plants between the two countries. ${ }^{278}$ Another goal was to discuss "future areas of cooperation and information exchange that will facilitate the safe incorporation of transgenic plants into agricultural production and commerce."279 Prior to this agreement, both countries were already performing case-by-case assessments of proposed GM plants prior to the plant being released. ${ }^{280}$ Representatives for the two countries believe that eventually there may be "mutual acceptance of assessment."281

Canada and the European Union have adopted the United Nations Cartagena Protocol on Biosafety. ${ }^{282}$ The United States, however, has only signed the United Nations Convention on Biological Diversity. ${ }^{283}$ The Cartagena Protocol is an international agreement to "establish common rules to be followed in transboundary movements of GMOs in order to ensure, on a global

275. See generally Canadian Food Inspection Agency, U.S. Dept. of Agriculture, Canada and United States 2001 Bilateral on Agricultural Biotechnology (1998), at http://www. inspection.gc.ca/english/plaveg/pbo/usda/cdausbilate.shtml (last visited Oct. 31, 2003) [hereinafter Canada and U.S.]. See generally EU Questions, supra note 228.

276. See Canada and U.S., supra note 275. The Canadian approach and the approach taken by the United States is similar, but it does vary, mainly in the way the regulatory schemes are split. See id. For example, CFLA and Health Canada are the two main agencies responsible for regulating GM plants, whereas in the United States that responsibility is split between FDA, EPA and USDA. See id.

277. See generally id.

278. Canada and U.S., supra note 275.

279. Id.

280. See id.

281. Id.

282. See The Cartagena Protocol on Biosafety, The Convention on Biological Diversity, available at http://www.biodiv.org/biosafety/protocol.asp\# (last visited Oct. 31, 2003) [hereinafter Protocol]. On April 19, 2001, Canada signed the Cartagena Protocol. Office of Biotechnology, Canadian Food Inspection Agency, Cartagena Protocol on Biosafety (2002), at http://www.inspection.gc.ca/english/sci/biotech/enviro/cartagenae.shtml (last visited Oct. 31, 2003). The European Union adopted the Cartagena Protocol on January 29, 2000 . EU QUESTIONS, supra note 228. The United States signed the Convention of Biological Diversity (CBD) but has not ratified the Biosafety Protocol. See Protocol, supra note 282. As of September 8, 2003, fifty-seven countries ratified the Cartagena Protocol on Biodiversity, including Austria, Barbados, Belarus, Cuba, Denmark, and Samoa. See id. There are 186 parties to the Convention on Biological Diversity. See id. Included in the parties to the CBD are Argentina, Brazil, Cyprus, Greece, Lesotho, Malta, Saint Kitts and Nevis, Spain, and Togo. See id.

283. See Protocol, supra note 282. The U.N. Convention on Biological Diversity led to the development of the Cartagena Protocol in an effort to "conserve biodiversity." Jonathan H. Adler, The Cartagena Protocol and Biological Diversity; Biosafe or Bio-Sorry, 12 GEO. INT'L Envtl. L. Rev. 761, 768 (2000). In June 1993, President Clinton signed the CBD. See id. 
scale, the protection of biodiversity and of human health."284 Article 15 of the Cartagena Protocol urges countries to conduct scientific risk assessments concerning the possible effects of a living modified organism. ${ }^{285}$ Both Canada and the European Union have regulations that require this type of scientific risk assessment prior to the release of a GM product. ${ }^{286}$ The Cartagena Protocol also sets up a "Biosafety Clearing-House"287 to "[f]acilitate the exchange of scientific, technical, environmental and legal information on ... living modified organisms." 288 Signatories to the Cartagena Protocol are expected to take the appropriate actions in order to "implement its obligations under this Protocol."289

It is difficult to compare regulatory enforcement of GM products between Canada, the United States, and the European Union. Unlike the sovergeign states of Canada and the United States, the European Union bears the power to enact the regulations, but must rely on the Member States to enforce the regulations. ${ }^{290}$ However, the European Union, through the European Commission, has a food safety "inspection service, which visits Member

284. EU Questions, supra note 228. Included in the general provisions of the Cartagena Protocol are the following:

- The Parties shall ensure that the development, handling, transport, use, transfer and release of any living modified organisms are undertaken in a manner that prevents or reduces the risks to biological diversity, taking also into account risks to human health ....

- Nothing in this Protocol shall be interpreted as restricting the right of a Party to take action that is more protective of the conservation and sustainable use of biological diversity than that called for in this Protocol, provided that such action is consistent with the objective and the provisions of this Protocol and is in accordance with that Party's other obligations under international law.

- The Parties are encouraged to take into account, as appropriate, available expertise, instruments and work undertaken in international forums with competence in the area of risks to human health.

Cartagena Protocol on Biosafety to the Convention on Biological Diversity, Jan. 29, 2000, art. 2, 39 I.L.M. 1027 [hereinafter Convention].

285. See id. art. 15.

286. See Schedule No. 948, supra note 100. See also CFIA Envtl. Questions, supra note 85; Novel Food Regulations (EC) 258/97; Commission Decision of 24 July 2002 Establishing Guidance Notes Supplementing Annex II to Directive 2001/18/EC of the European Parliament and of the Council on the Deliberate Release into the Environment of Genetically Modified Organisms and Repealing Council Directive 90/220/EEC, 2002 O.J. (L 200) 22. The United States has a similar requirement for a scientific risk assessment to be performed prior to the release of a genetically engineered product. See Genetically Engineered Organisms and Products; Simplification of Requirements and Procedures for Genetically Engineered Organisms, 7 C.F.R. $\$ 340$ (May 2, 1997). See also Pre-market Notice Concerning Bioengineered Foods, 21 C.F.R $\S 192$ (proposed Jan. 18, 2001).

287. Convention, supra note 284 , art. 20. The Biosafety Clearing-House will "serve as a means through which information is made available. . . It shall also provide access, where possible, to other international biosafety information exchange mechanisms." Id.

288. Id.

289. Id. art. 2(1).

290. See generally Europa, supra note 225. 
States on a regular basis." ${ }^{291}$ The inspection service has shown that amongst the Member States, "there are wide variations in the manner in which Community legislation is being implemented and enforced."292 Canada and the United States have agencies in place to regulate all aspects of GM products found in their jurisdictions. ${ }^{293}$ The creation of the EFSA will allow the European Union to enjoy the consistency a national regulatory agency can provide. ${ }^{294}$

A notable difference between the European Union, Canada, and the United States, is the amount of GM products each has approved. While Canada and the United States have each approved several GM products, the European Union has approved only a small number of GM products. ${ }^{295}$ In fact, the European Union has only approved three food products containing GMOs whereas Canada has approved forty-two GM products and the United States has approved fifty-three. ${ }^{296}$ One possible reason for this may be consumer acceptance of GM food products. ${ }^{297}$ In both Canada and the United States, consumers accept GM food products with little complaint. ${ }^{298}$ However, the opposite is true in the European Union and many of its Member States. ${ }^{299}$ Product safety dominates the public GM product debate in the European Union. ${ }^{300}$ In fact, one activist against genetically modified food products, Jose Bove, has been charged with destroying GM rice plants in France. ${ }^{301}$ Moreover, consumer acceptance can be reflective of the labeling laws of the individual countries. ${ }^{302}$ The European Union applies very strict labeling regulations

291. White Paper, supra note 250 , at 4.

292. Id. The Commission proposed to set up a "Community framework for the development and operation of national control systems." Id.

293. See generally Response, supra note 70; U.S. Regulatory Oversight, supra note 153.

294. See generally EFSA, supra note 250.

295. See Schedule No. 948, supra note 100. See also Completed Consultations, supra note 13; Authorisation, supra note 229.

296. See Authorisation, supra note 229. See also Schedule No. 948 , supra note 100. See also Completed Consultations, supra note 13.

297. See Marsha A. Echols, Food Safety Regulations in the European Union and the United States: Different Cultures, Different Laws, 4 COLUM. J. EUR. L. 525, 535-37 (1998).

298. See id. at 543.

299. See id. at 536-37.

300. See id. "Greenpeace, Friends of the Earth and other non-governmental organizations in Europe have fought a well-publicized battle against the introduction of genetically modified corn and soybeans there." Id. at 536.

301. See Bove on Trial for Wrecking Genetic Rice, (Feb. 8, 2001), available at http://edition.cnn.com/2001/WORLD/europe/france/02/08/crime.france.bove/ (last visited Oct. $31,2003)$.

302. See generally FAO Ethics, supra note 3, at 23. In the United States, if GM food products "are not different from their traditional counterparts in terms of nutrition, composition or safety, labelling is considered to be unnecessary." Id. However, "[i]n the European Union, the question is not whether to label products of biotechnology, but how to label them." Id. Canada requires labeling "for novel foods, including those obtained through biotechnology, where safety concerns (e.g., allergens) that could be mitigated through labelling, or changes in composition or nutrition, are identified." See Response, supra note 70, 993. 
applying to GM products whereas the United States labeling laws do not specifically address GM products. ${ }^{303}$ However, the United States just passed an organic labeling law stating that any food product labeled as organic food must not have "mingled with genetically modified organisms." 304 Canada's labeling laws are similar to those found in the United States in that novel foods need to be labeled when there are safety concerns, such as allergens, ${ }^{305}$

\section{CONCLUSION}

[G]enetically modified organisms (GMOs), like all the new technologies, are instruments that can be used for good and for bad in the same way that they can be either democratically managed to the benefit of the most needy or skewed to the advantage of specific groups that hold the vital political, economic and technological power. ${ }^{306}$

Biotechnology has already become integrated into our world through the production of certain pharmaceutical products and more recently through genetically modified plants and food. ${ }^{307}$ In some, if not most, countries around the world, biotechnology has also become somewhat commonplace in the market. ${ }^{308}$ However, there is no common international agreement as to the

303. See EU Questions, supra note 228. The European Union wants consumers to be able to make an informed choice about the food they are going to consume and therefore require labeling to "indicate the presence of GMOs." Id. Meanwhile, the United States just passed (Oct. 21, 2002) new standards for the labeling of organic food. See Judith Graham, Organic Food Seal to Root Out Imitators, INDIANAPOLIS STAR, Oct. 20, 2002, at A7. This standard will allow for a label that states the given food product does not contain any GMOs, but otherwise the United States does not require food-containing GMOs to be labeled as such. See id.

304. Graham, supra note 303. The new organic food seal also requires that the food has "never been sprayed with pesticides, shot up with antibiotics, treated with sewage sludge, injected with growth hormones, exposed to irradiation or mingled with" GM organisms. Id.

305. See Response, supra note 70, 193.

306. FAO Ethics, supra note 3.

307. See KLUG \& CUMMINGS, supra note 6, at 432.

308. See Office of Scientific Analysis and Support, U.S. Food and Drug Admin., Report on Consumer Focus Groups on Biotechnology (2000), available at http://vm.cfsan.fda.gov/ $\sim$ comm/biorpt.html (last visited Oct. 31, 2003). In the United States, genetically engineered products can be found in "cake mix, corn oil, canola oil, [F]lavr [S] avr tomato, vitamin A rice, and growth hormone salmon." Id. In September 1999, the following food products were found to be GM food products:

Frito-Lay Corn Chips, Bravo's Tortilla Chips, Kellogg's Corn Flakes, General Mills Total Corn Flakes Cereal, Post Blueberry Morning Cereal, Heinz 2 Baby

Food, Enfamil ProSobee Soy Formula, Similac Isomil Soy Formula, Nestle Carnation Alsoy Infant Formula, Quaker Chewy Granola Bars, Nabisco Snackwell's Granola Bars, Ball Park Franks, Duncan Hines Cake Mix, Quick Loaf Bread Mix, Ultra Slim Fast, Quaker Yellow Corn Meal, Light Life Gimme Lean, Aunt Jemima Pancake Mix, Alpo Dry Pet Food, Gardenburger, Boca 
acceptance of GM products. ${ }^{309}$ GM products that are accepted in one country might be banned in another. ${ }^{310}$ Food products that contain GMOs may be found in abundance in marketplaces throughout Canada and the United States. ${ }^{311}$ However, it is unlikely that one could find the same food products in the European Union. ${ }^{312}$ Consumer acceptance, and indeed consumer knowledge varies greatly between the European Union, Canada, and the United States. ${ }^{313}$ In the EU, consumer knowledge about GMOs is high, possibly because of the labeling laws and activists, and consumer acceptance is low. ${ }^{314}$ However, in the United States and Canada, consumers seem to either not know about GM products or are not opposed with as much vehemence as their European counterparts. ${ }^{315}$

The governments of Canada, the United States, and the European Union take an active role in determining the potential risks GMOs pose to human health and the environment. ${ }^{316}$ Each of the three governments requires extensive scientific risk assessments to occur prior to releasing a GMO into the environment or into the marketplace. ${ }^{317}$ Each government also appears to be

\footnotetext{
Burger Chef Max's Favorite, Morning Star Farms Better'n Burgers, Green Giant Harvest Burgers (now called Morningstar Farms), McDonald's McVeggie Burgers, Ovaltine Malt Powdered Beverage Mix, Betty Crocker Bac-O's Bacon Flavor Bits, Old El Paso Taco Shells, Jiffy Corn Muffin Mix.
}

Id.

309. See Convention, supra note 284 , art. 20, at 1027. Although the Cartagena Protocol would offer some international stability as to genetically modified foods, it has only been ratified by fifty-seven countries. See Protocol, supra note 282.

310. See Authorisation, supra note 229. See also Schedule No. 948, supra note 100; Completed Consultations, supra note 13. 13.

311. See Schedule No. 948, supra note 100. See also Completed Consultations, supra note

312. See Authorisation, supra note 229.

313. See generally Echols, supra note 297.

314. See id.

315. See generally Transgenic Fish, supra note 205. The FDA acknowledges that "[a]pproval by FDA or a food regulatory group in another country does not guarantee public acceptance." Id. The fact that so many products containing GMOs are commonly found in the United States suggests that either people do not know that products contain GMOs or that they are not opposed to GMOs being in the food product because consumer acceptance tends to rule the market place. If consumers stop buying an item, eventually the stores will stop selling that item. See generally Gale, supra note 9.

316. See generally Response, supra note 70. See generally U.S. Regulatory Oversight, supra note 153. See also Authorisation, supra note 229; Schedule No. 948, supra note 100; Completed Consultations, supra note 13; CFIA Envtl. Questions, supra note 85; Novel Food Regulations (EC) 258/97; Commission Decision of 24 July 2002 Establishing Guidance Notes Supplementing Annex II to Directive 2001/18/EC of the European Parliament and of the Council on the Deliberate Release into the Environment of Genetically Modified Organisms and Repealing Council Directive 90/220/EEC, 2002 O.J. (L 200) 22; Genetically Engineered Organisms and Products; Simplification of Requirements and Procedures for Genetically Engineered Organisms, 7 C.F.R. $\$ 340$ (May 2, 1997); Pre-market Notice Concerning Bioengineered Foods, 21 C.F.R $\S 192$ (proposed Jan. 18, 2001).

317. See CFIA Envtl. Questions, supra note 85 . See also Commission Decision of 24 July 2002 Establishing Guidance Notes Supplementing Annex II to Directive 2001/18/EC of the 
doing all that it can to protect its jurisdiction from the known and unknown risks associated with new technology. ${ }^{318}$

However, some issues concerning biotechnology must be addressed on an international level. Such issues include third world access to biotechnology in an effort to reduce world hunger. ${ }^{319}$ International agreements, such as the Cartagena Protocol are efforts to address the ethical and global health considerations of biotechnology. ${ }^{320}$ Biotechnology can be a benefit for those that have opportunity to take advantage of the technology. ${ }^{321}$ Genetic engineering can create pest resistant vegetables, reducing the need for chemical pesticides. ${ }^{322}$ Genetic engineering can also enable fish to grow at a faster rate, thus reducing the amount of time and money spent to raise them. ${ }^{323}$ Nonetheless, care should be taken to ensure the safety of these novel products. If neutral experts find such products safe for humans and the environment, these products should be offered so that the public can decide the fate of GM products. Who knows, maybe one day soon you will sit down at your favorite restaurant and order the house special-fried chicken with the health benefits of steamed spinach. ${ }^{324}$

European Parliament and of the Council on the Deliberate Release into the Environment of Genetically Modified Organisms and Repealing Council Directive 90/220/EEC, 2002 O.J. (L 200) 22; Genetically Engineered Organisms and Products; Simplification of

Requirements and Procedures for Genetically Engineered Organisms, 7 C.F.R. $\$ 340$ (May 2, 1997); Pre-market Notice Concerning Bioengineered Foods, 21 C.F.R $\S 192$ (proposed Jan. 18, 2001).

318. See CFIA Envtl. Questions, supra note 85. See also Commission Decision of 24 July 2002 Establishing Guidance Notes Supplementing Annex II to Directive 2001/18/EC of the European Parliament and of the Council on the Deliberate Release into the Environment of Genetically Modified Organisms and Repealing Council Directive 90/220/EEC, 2002 O.J. (L 200) 22; Genetically Engineered Organisms and Products; Simplification of Requirements and Procedures for Genetically Engineered Organisms, 7 C.F.R. $\$ 340$ (May 2, 1997); Pre-market Notice Concerning Bioengineered Foods, 21 C.F.R $\$ 192$ (proposed Jan. 18, 2001).

319. See generally FAO Ethics, supra note 3.

320. See Cartagena Protocol on Biosafety to the Convention on Biological Diversity, Jan. 29, 2000, 39 I.L.M. 1027.

321. See generally FAO Ethics, supra note 3.

322. See KLUG \& CUMMINGS, supra note 6, at 432.

323. See Lewis, supra note 5.

324. See generally Young, supra note 1. 
